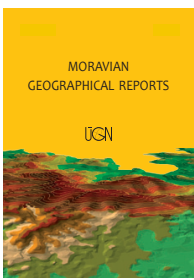

MORAVIAN GEOGRAPHICAL REPORTS

\title{
A functional interaction approach to the definition of meso regions: The case of the Czech Republic
}

\author{
Martin ERLEBACH $^{\text {a }}$, Martin TOMÁŠ ${ }^{a}$, Petr TONEV ${ }^{b}$
}

\begin{abstract}
The definition of functional meso regions for the territory of the Czech Republic is articulated in this article. Functional regions reflect horizontal interactions in space and are presented as a useful tool for various types of geographical analyses, and also for spatial planning, economic policy designs, etc. This paper attempts to add to the discussion on the need to delineate areal units at different hierarchical levels, and to understand the functional flows and spatial behaviours of the population in a given space. Three agglomerative methods are applied in the paper (the CURDS regionalisation algorithm, Intramax, and cluster analysis), and they have not been used previously in Czech geography for the delineation of functional meso regions. Existing functional regions at the micro-level, based on daily travel-to-work flows from the 2001 census, have served as the building blocks. The analyses have produced five regional systems at the meso level, based on daily labour commuting movements of the population. Basic statistics and a characterisation of these systems are provided in this paper.
\end{abstract}

Key words: functional region, local labour market area, travel-to-work flows, meso regional level, functional regionalisation, Intramax, Czech Republic

Article history: Received 4 November 2015; Accepted 10 May 2016; Published 30 June 2016

\section{Introduction}

The definition of functional regions has played an important role in geographical and spatial research for several decades. The organisation of a space is crucial for an understanding of and an explanation for socio-economic phenomena, and is necessary for the needs of regional development, territorial planning and the implementation of regional policies. Functional regions based on daily travel-to-work flows appear to be a very useful tool in finding a solution to a number of socio-economic issues, unlike administrative or political areal units, which often ignore real geographic functional linkages. Suitably-defined functional regions for a particular research task can avoid the spatial bias caused by the incorrectly defined borders of administrative units (Wong, 2009). In many OECD countries, functional regions are used as statistical units for various analyses (OECD, 2002).

Geographic research often works on various hierarchical levels. The definition of functional regions is no exception (Drobne and Bogataj, 2012; Halás et al., 2014a). Functional regions defined at various hierarchical levels can be used to solve different socio-economic problems. Functional regions can be understood as the spatial delineation of the spheres of influence of settlement system centres. These centres are hierarchically organised according to their significance (size, function), and, obviously, so are the functional regions. In this respect, meso regions identify the spheres of influence of meso regional centres in a settlement system, in this case the Czech Republic. Functional regions at the micro level, such as local labour market areas (LLMA) (Ball, 1980), can be used for labour market analyses, the implementation of local employment policies and the identification of regional disparities, while functional regions at the meso level can serve as a tool for regional planning (regional development strategies).

The definition of functional meso regions and the identification of the main intraregional interactions can also benefit the optimisation of transport systems of a regional and inter-regional importance. Variants of functional meso regions discussed in this paper conform to the NUTS 2 definitions, possibly to the NUTS 3 level in terms of their size. The definition of NUTS regions, however, is based on administrative concepts, unlike the presented variants of functional meso regions. Presently, meso regions (NUTS 3

\footnotetext{
${ }^{a}$ Department of Geography, Faculty of Science, Palacký University Olomouc, Czech Republic (*corresponding author: Martin Erlebach, e-mail: Martin.Erlebach@seznam.cz)

${ }^{\mathrm{b}}$ Department of Regional Economics and Administration, Faculty of Economics and Administration, Masaryk University, Brno, Czech Republic
} 
and 2 levels) are used for the implementation of particular EU policies. Each hierarchical level of a functional region can be suitable for the solution of various tasks, therefore it is important to differentiate between them.

The daily rhythm of population movements, particularly daily travel-to-work flows, is a determinative process in the formation of regional systems at the micro level. Based on their flow patterns and further criteria, various types of functional regions can be defined (Klapka et al., 2013a; Erlebach et al., 2014). Similarly, as in the case of the definition of functional micro regions, daily travel-to-work flows are also determinative for the identification of functional meso regions (Halás et al., 2014b). The daily labour commuting rhythm (daily travel-to-work flows) is an aggregation of the regular movements of individuals, describing spatial behaviours for a considerable part of the population. These movements are relatively stable over time (unlike travel for retail services, for example). The frequency of retailing trips and commuting for services, however, is decreasing and they can no longer be considered as regular daily movements (Halás and Zuskáčová, 2013; Halás et al., 2014b).

The main objective of this paper is to define meso regions for the territory of the Czech Republic, using several acknowledged functional interaction approaches. Micro regions (functional regions based on daily travel-to-work flows from the 2001 census, variant FRD 2B) defined by Klapka et al. (2014), serve as the building blocks for the analyses presented. A subsequent objective of the paper is to apply three methods for the definition of functional meso regions, which either were not applied in the Czech Republic at all, or were used only to define functional micro regions. The first method applies the adjusted variant of the CURDS regionalisation algorithm to the delimitation of LLMAs (Coombes, et al., 1986; Coombes, 2010). The second method applies the Intramax regionalisation procedure (Masser and Brown, 1975). The third method uses the approach of a general cluster analysis (e.g. Ward, 1963). The paper also provides the relevant characteristics for, and an assessment of the resulting meso regional systems (see for example, Klapka et al., 2014; Konjar et al., 2010).

\section{Functional regions and methods for their definition}

The term functional region was introduced into geography in the second half of the $20^{\text {th }}$ century (Philbrick, 1957; Nystuen and Dacey, 1961; Haggett, 1965). The term was inspired by the theories and work of spatial economists (von Thünen, 1826; Christaller, 1933; Lösch, 1940; Isard, 1956). Since then the concept of a functional region has gone through many adjustments (Sýkora and Mulíček, 2009). The primary characteristics of a functional region are its size and its self-containment in relation to its surroundings (Coombes et al., 1986; CasadoDíaz, 2000; Klapka et al., 2013a). Size can be expressed as the population, the number of jobs or some other relevant criterion. Self-containment requires the maximising of the flows within a particular region: at least $50 \%$ of the flows incident to a region should occur within its boundaries (Smart, 1974; Farmer and Fotheringham, 2011).

The research literature also provides slightly different views on the definition of a functional region. The OECD (2002) sees it as an areal unit based on socio-economic linkages, regardless of historical and physical geographical conditions. Karlsson and Olsson (2006) see a functional region as an area with a high frequency of socio-economic interactions which occur within the region. Similarly, Sýkora and Mulíček (2009) see a functional region as an area which contains the integrated socio-economic activities of the population. In the geographical literature, several specific types of functional regions can be observed, based on specific characteristics, particularly regarding the type and pattern of region-organising interaction.

The first such instance is a functional urban region (FUR), which is determined by the specific character of its core (Bezák, 2000; Karlsson and Olsson, 2006). A core should have an urban character in this case and interactions should be directed at this core. A similar instance, often confused with the former, is a daily urban system (DUS). Daily urban systems (Berry, 1973) are based on a more complex concept of the limits of a spatial economy (coherence and self-containment), where differences between a core and its adjacent hinterland are less distinct (Hall and Hay, 1980). Unlike the preceding type, DUS is based on daily interactions, and the daily rhythm of flows is significant. Local labour market areas (LLMA) and travel-to-work areas (TTWA) are almost near-synonyms. Local labour market areas (Smart, 1974) are considered to have a slightly wider meaning than travel-to-work areas (Ball, 1980). They need not necessarily be based on labour commuting, but in practice they are, almost without exception. Travel-to-work areas directly refer to the region-organising process, while local labour market areas first refer to their applied use, such as labour market analysis and the implementation of labour market policy (Tonev, 2013).

Basically, three approaches to the definition of functional regions can be identified: a) a graph-theoretic approach; b) a numerical taxonomy approach; and c) a rule-based approach. Graph-theoretic methods are based on the analysis of significant flows and have a long tradition in geographical research (Nystuen and Dacey, 1961; Holmes and Haggett, 1977). The graph-theoretic approach has even been used in some recent regionalising tasks, albeit in its more sophisticated form (Karlsson and Olsson, 2006; and recently via three-step procedure by Kropp and Schwengler, 2014). Methods of numerical taxonomy (e.g. Brown and Holmes, 1971; Masser and Brown, 1975) are based on the analysis of functional (taxonomic) distances. The rulebased / multistage methods were proposed, for example, by Smart (1974) and Coombes, et al. (1982, 1986). The latter proposal represents a relatively complex regionalisation algorithm which has probably had the greatest response from geographical researchers (see Casado-Díaz, 2000; Papps and Newell, 2002; Drobne et al., 2009; Konjar et al., 2010; Bezák, 2000; Halás et al., 2014a, b; Klapka et al., 2013b, 2014; Tonev, 2013). Application of the latter two approaches is a part of this contribution.

All approaches have their pros and cons (see for example, Coombes, 2010; Mitchell and Watts, 2010; Landré, 2012; Landré and Håkansson, 2013). Clustering methods (numerical taxonomy methods) are based on a selected criterion, which is gradually decreased until all the resulting regions meet it (Watts, 2009). The Intramax procedure is seen by Masser and Scheurwater (1980) as a suitable method for the analyses of large data sets and the amalgamation of regions on the basis of the strongest links, without their dissolution during later stages of analysis. On the other hand, these methods are not able to make amendments during the running of the procedure. Multistage methods are able to set several criteria for each 
step in a procedure and to control the required size and selfcontainment of the resulting regions (Coombes et al., 1986; Coombes, 2010; Casado-Díaz, 2000; Halás et al., 2015).

\section{Procedures}

The first step in the analysis was to identify the basic building blocks (basic spatial units) to be amalgamated into meso regions. All four variants of functional micro regions as defined by Klapka et al. (2014) were tested using three different regionalisation methods. An extensive set of the systems of functional meso regions resulted from the analysis. For the purposes of this paper, five variants of functional meso regions were selected on the basis of maximising the total self-containment of respective regional systems. All of these five variants were based on the functional micro regional system FRD 2B (Klapka et. al., 2014); its characteristics are presented in Table 1 , where the $\beta_{1}$ and $\beta_{2}$ values determine the lower and upper limits of the selfcontainment of functional micro regions, and the $\beta_{3}$ and $\beta_{4}$ values determine the lower and upper limits of the size of functional micro regions.

For further analysis, these functional micro regions were arranged into a square interaction matrix $(98 \times 98$ cells), which stored intra-regional and inter-regional flows. This matrix was the basis for the application of the three regionalisation approaches.

\subsection{The local labour market area approach}

The most well-known and acknowledged multistage procedure for defining functional regions (local labour market areas in this case) was developed by the Centre for Urban and Regional Development Studies (CURDS), see Coombes et al., 1982, 1986), and Coombes (2010). In this paper its adjusted third variant (Coombes and Bond, 2008; Coombes, 2010) has been applied. The adjustments are discussed in Halás et al. (2015). The third variant has a more general hierarchical clustering character - from the beginning of the procedure it considers all basic spatial units as proto-regions. A successful solution is identified through the use of the constraint function, which controls the trade-off between the self-containment and the size of resulting regions, where the upper and lower limits of selfcontainment and size are set by the researcher. The values for these four parameters $\left(\beta_{1}, \beta_{2}, \beta_{3}\right.$ and $\left.\beta_{4}\right)$ have resulted from extensive testing and are presented in Table 2 . The size parameter is based on the number of employed persons. The amalgamation of basic spatial units (proto regions) is based on Smart's measure (Smart, 1974), which is expressed by the formula:

$$
\frac{T_{i j}^{2}}{\left(\sum_{k} T_{i k} * \sum_{k} T_{k j}\right)}+\frac{T_{j i}^{2}}{\left(\sum_{k} T_{j k} * \sum_{k} T_{k i}\right)}
$$

where $T_{i j}$ is the flow from spatial unit $i$ into spatial unit $j, T_{j i}$ is the flow from spatial unit $j$ to spatial unit $i$, $\sum_{k} T_{i k}$ denotes all out-going flows from $i, \sum_{k} T_{k j}$ denotes all in-going flows to $j, \sum_{k} T_{j k}$ denotes all out-going flows from $j$, and $\sum_{k} T_{k i}$ denotes all in-going flows to $i$. After each amalgamation the interaction matrix is updated. An indisputable benefit of this method is that it is possible to set and adjust input parameters for the need to optimise the resulting regional systems.

\subsection{The Intramax approach}

The second approach to defining functional meso regions in this paper is based on maximising intraregional flows - Intramax (Masser and Brown, 1975). The Intramax algorithm identifies functional regions through the hierarchical aggregation of basic spatial units, with the objective of forming homogeneous clusters (Landré, 2012). The interaction measure is used as an objective function in the hierarchical clustering algorithm and it can be expressed by the formula:

$$
\frac{T_{i j}}{\left(\sum_{k} T_{i k} * \sum_{k} T_{k j}\right)}+\frac{T_{j i}}{\left(\sum_{k} T_{j k} * \sum_{k} T_{k i}\right)} \rightarrow \max
$$

The Intramax is a bottom-up procedure, which starts with the same number of clusters as the number of basic spatial units. These clusters are gradually amalgamated until one cluster is formed which consists of all basic spatial units (de Jong and van der Vaart, 2010). Thus, the Intramax is a stepwise analysis: there are $n$ basic spatial units, and $(n-1)$ steps. The objective of the method is to maximise the share of the inner interactions of a region in the sum of column and row values of the interaction matrix (Masser and Brown, 1975). The adjusted standardised matrix is an input in the aggregation procedure. The Intramax method uses, for the standardisation of the interaction matrix, the following formula:

$$
\sum_{i=1}^{N} \sum_{j=1}^{N} a_{i j}=1
$$

where $a_{i j}$ is a value for an input matrix cell. Each pair of regions is examined separately in each step and is amalgamated on the basis of the maximum value for the

\begin{tabular}{|c|c|c|c|c|c|c|c|c|}
\hline$\beta_{1}$ value & $\beta_{2}$ value & $\beta_{3}$ value & $\beta_{4}$ value & $\begin{array}{c}\text { Self- } \\
\text { containment } \\
\text { of reg. } \\
\text { system }\end{array}$ & $\begin{array}{l}\text { Number of } \\
\text { regions }\end{array}$ & $\begin{array}{c}\text { Self- } \\
\text { containment } \\
(\text { mean })\end{array}$ & $\begin{array}{c}\text { Self- } \\
\text { containment } \\
\text { (median) }\end{array}$ & $\begin{array}{c}\text { Self- } \\
\text { containment } \\
\text { (var. coef.) }\end{array}$ \\
\hline 0.63 & 0.75 & 6,000 & 70,000 & 0.915 & 98 & 0.828 & 0.835 & 0.064 \\
\hline $\begin{array}{l}\text { Economically } \\
\text { active } \\
\text { population } \\
\text { (mean) }\end{array}$ & $\begin{array}{c}\text { Economically } \\
\text { active } \\
\text { population } \\
\text { (median) }\end{array}$ & $\begin{array}{c}\text { Economically } \\
\text { active } \\
\text { population } \\
\text { (var. coef*) }\end{array}$ & $\begin{array}{l}\text { Population } \\
\text { (mean) }\end{array}$ & $\begin{array}{l}\text { Population } \\
\text { (median) }\end{array}$ & $\begin{array}{l}\text { Population } \\
\text { (var. coef.*) }\end{array}$ & $\begin{array}{c}\text { Area km² } \\
\text { (mean) }\end{array}$ & $\begin{array}{c}\text { Area km² } \\
\text { (median) }\end{array}$ & $\begin{array}{c}\text { Area km² } \\
\text { (var. coef.*) }\end{array}$ \\
\hline $53,606.12$ & $37,351.00$ & 1.450 & $104,388.40$ & $75,130.50$ & 1.391 & 805.24 & 736.86 & 0.468 \\
\hline
\end{tabular}
objective function. The objective function can be calculated only if all $\sum_{k} T_{i k}>0$ and all $\sum_{k} T_{k j}>0$ (Landré, 2012).

Tab. 1: Characteristics of regional system FRD 2B. Source: Klapka et al. (2014)

Note: *var. coef. = Coefficient of variation 


\subsection{Cluster analysis approach}

The third approach used in this paper to define functional meso regions comes from general cluster analysis methods. Each basic spatial unit is initially considered as a cluster and the procedure runs until all basic spatial units form one single cluster. The interaction matrix in this case is considered to be a matrix of the taxonomic distances (taxonomic dissimilarities) between individual basic spatial units and it was relativised by the CURDS interaction measure (Coombes, et al., 1982):

$$
\frac{T_{i j}}{\sum_{k} T_{i k}}+\frac{T_{i j}}{\sum_{k} T_{k j}}+\frac{T_{j i}}{\sum_{k} T_{j k}}+\frac{T_{j i}}{\sum_{k} T_{k i}}
$$

If absolute values for interaction enter the clustering process, there is a disadvantage when the analysis of taxonomic distances (dissimilarities) clusters typologically similar basic spatial units, in this case units with a similar structure of interactions and not units with strong mutual linkages. Therefore the input matrix values have to be "relativized" and correlated. More concretely, the values in the interaction matrix have been normalised by the above-mentioned interaction measure (CURDS). The values in the normalised matrix have been correlated by the use of Pearson's coefficient. The analysis produces a dendrogram, where, on the $\mathrm{x}$ axis, there are basic spatial units and on the y axis there are distances (similarities) between clusters. The Silhouette method (Rousseeuw, 1987) has been used for validation of the resulting dendrogram. This method calculates the value of the width of silhouette for each object, the mean value of the width of a silhouette for each cluster, and the mean value of the width of silhouette for the whole data set. This approach compares mean silhouette widths for a given cluster. Silhouette represents the proportion of similarity and dissimilarity to other clusters.

The calculation of the Silhoutte coefficient is done in three consequent steps. Firstly for each object $(i)$ its average distance $\left(a_{i}\right)$ to all remaining objects in a cluster is calculated. Secondly for each object $(i)$ and any cluster not containing the object, the object's average distance from all the objects in the given cluster is calculated. The minimum value $\left(b_{i}\right)$ is found with respect to all clusters. Finally for the object $(i)$ the Silhouette coefficient is calculated according to:

$$
s_{i}=\left(b_{i}-a_{i}\right) / \max \left(a_{i}, b_{i}\right)
$$

The measurement of similarity of basic spatial units and their clustering into meso regions is based on the Euclidean distance:

$$
\mathrm{d}_{\mathrm{r}}\left(\mathrm{x}_{\mathrm{i}}, \mathrm{x}_{\mathrm{j}}\right)=\sqrt{\sum_{m=1}^{p}\left(x_{i m}-x_{j m}\right)^{2}}
$$

where $d_{r}\left(x_{i}, x_{j}\right)$ is the taxonomic distance between object $i$ and $j, x_{i m}$ is the value of criterion $m$ for object $i$, and $x_{j m}$ the value of criterion $m$ for object $j$. There are several approaches to the clustering of objects on the basis of their taxonomic distance or similarity (Gustafson, 1973). In this paper, Ward's method, based on the loss of information during clustering, has been applied (see Ward, 1963: 239-243). The clustering criterion is the total sum of square errors of each object from the group centroid, to which it belongs.

\section{Results and discussion}

Table 2 presents the basic statistics for five functional meso regional systems, where systems M-FRD $1 \mathrm{~A}$ and $1 \mathrm{~B}$ were produced by the multistage local labour market area approach, systems M-FRD 2A and 2B were produced by the cluster analysis approach, and system M-FRD 3 was produced by the Intramax approach. The Job Ratio function has been calculated according to:

$$
\frac{\sum_{j} T_{j i}}{\sum_{j} T_{i j}}
$$

If its value exceeds 1 , the region offers more jobs than the number of employed persons in the region. Table 2 comprises three types of self-containment. The first type was proposed by Halás, et al., (2015) and is calculated by:

$$
\frac{T_{j j}}{\left(\sum_{k} T_{j k}+\sum_{k} T_{k j}\right)-T_{j j}} .
$$

The remaining two types of self-containment (CasadoDíaz, 2003) express the so called supply-side self-containment:

$$
\frac{T_{i i}}{\sum_{j} T_{i j}}
$$

and demand-side self-containment:

$$
\frac{T_{i i}}{\sum_{j} T_{j i}}
$$

The former expresses the share of employed persons working locally out of the total employed persons in the region, while the latter expresses the share of employed persons working locally out of the total number of jobs in the region.

Five variants of functional meso regional systems of the Czech Republic are presented in figures 1-5, and laid over basic physical geographical conditions. The largest cities in each meso region (in terms of the number of employed persons) are labelled on the maps. The inner structure of meso regions and inter-regional interactions are also presented on the maps. The relationships between basic spatial units (functional micro regions - see Fig. 6 for their names) are used for this purpose, and three ways of representing the interactions are used in order to provide the highest diversity of views on the Czech regional system. Thus, the inter-regional relationships are based on the Smart's measure (Figs. 1 and 2), the CURDS measure (Figs. 3 and 4) and the absolute numbers for daily travelto-work flows (Fig. 5). It should be noted here that all three were applied to all five meso regional systems; the selection presented in this paper is a result of limited space.

The variant M-FRD 1A (Fig. 1) consists of eight meso regions. The lowest level of self-containment $(0.959)$ is in the meso region in eastern Bohemia (Hradec Králové), with significant cross-border interactions between the pairs of micro regions Jičín-Mladá Boleslav, Vrchlabí-Semily, and Vysoké Mýto-Svitavy. In contrast, the highest level of selfcontainment (0.981) is in the region of northern Moravia and Silesia (Ostrava), with strong interactions within this region. The overall pattern of this meso regional system very markedly resembles the administrative regional division of Bohemia as it has existed in the Czech Republic (Czechoslovakia) since 1960. In Moravia and Silesia, 


\begin{tabular}{lccccc}
\hline \multicolumn{1}{c}{ Attributes for regional systems } & M-FRD 1A & M-FRD 1B & M-FRD 2A & M-FRD 2B & M-FRD 3 \\
\hline$\beta_{1}$ (self-containment, lower limit) & 0.8 & 0.75 & $\mathrm{x}$ & $\mathrm{x}$ & $\mathrm{X}$ \\
$\beta_{2}$ (self-containment, upper limit) & 0.9 & 0.85 & $\mathrm{x}$ & $\mathrm{x}$ & $\mathrm{X}$ \\
$\beta_{3}$ (size of region, lower limit) & 290,000 & 250,000 & $\mathrm{x}$ & $\mathrm{x}$ & $\mathrm{X}$ \\
$\beta_{4}$ (size of region, upper limit) & 300,000 & 251,000 & $\mathrm{x}$ & $\mathrm{x}$ & $\mathrm{X}$ \\
Number of regions & 8 & 9 & 12 & 8 & 9 \\
Size (mean) & 554,332 & 492,740 & 369,555 & 554,332 & 492,740 \\
Size (median) & 522,015 & 484,429 & 288,810 & 521,781 & 380,693 \\
Job ratio function (mean) & 1.008 & 0.994 & 0.942 & 0.959 & 0.919 \\
Job ratio function (median) & 0.668 & 0.741 & 0.756 & 0.682 & 0.858 \\
Self-containment (mean) & 0.969 & 0.965 & 0.957 & 0.969 & 0.965 \\
Self-containment (median) & 0.968 & 0.965 & 0.958 & 0.970 & 0.968 \\
Population (mean) & $1,278,758$ & $1,136,673$ & 852,505 & $1,278,758$ & $1,136,673$ \\
Population (median) & $1,261,083$ & $1,111,630$ & 643,953 & $1,261,554$ & 852,794 \\
Supply-side self-containment (mean) & 0.983 & 0.981 & 0.976 & 0.983 & 0.981 \\
Supply-side self-containment (median) & 0.984 & 0.982 & 0.975 & 0.984 & 0.982 \\
Demand-side self-containment (mean) & 0.986 & 0.984 & 0.980 & 0.986 & 0.984 \\
Demand-side self-containment (median) & 0.987 & 0.984 & 0.983 & 0.986 & 0.985 \\
\hline
\end{tabular}

Tab. 2. Characteristics for variants of meso regional systems of the Czech Republic. Sources: authors' computations

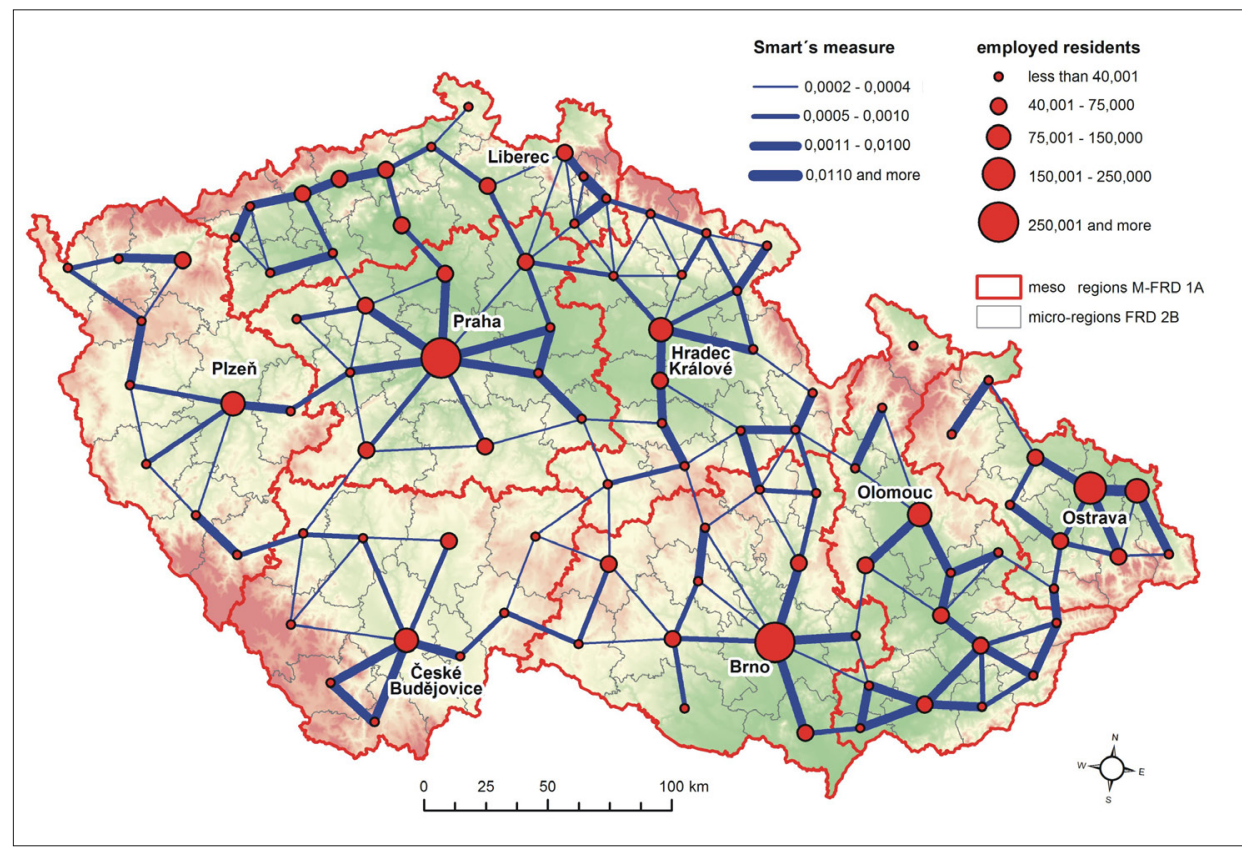

Fig. 1: Regional system M-FRD 1A. Sources: authors' elaboration, Klapka et al., (2014)

however, there is no such significant resemblance. Minor changes in the parameters of the constraint function (slightly lower values for size and self-containment) have produced the variant M-FRD 1B (Fig. 2). In this case the meso region in central Moravia has been split into two (Olomouc and Zlín), with the latter having the lowest level of self-containment (0.952), because of strong crossborder interactions between the pairs of micro regions Kroměříž-Přerov and Vsetín-Valašské Meziř́čí. These two variants can be considered as the most suitable for further geographical and socio-economic analyses. In our opinion, they best reflect the geographic space of the Czech Republic and respect a large portion of the country's natural geographic boundaries.
The two variants of functional meso regions (M-FRD 2A, see Fig. 3; M-FRD 2B, see Fig. 4) result from a single run of the regionalisation procedure based on the cluster analysis approach. Both variants of meso regional systems have been derived from a dendrogram, where the analysis of the procedure based on the Silhouette method offered two possibilities corresponding to the meso level. The highest average values for the Silhouette coefficient correspond for 8 and 12 clusters (i.e. meso regions); in other words, for 8 and 12 clusters there were the most distinct differences between two consequent taxonomic distances in both directions. Inter-regional interactions between constituent functional micro regions are expressed through the values of the CURDS interaction measure (as was noted earlier), 


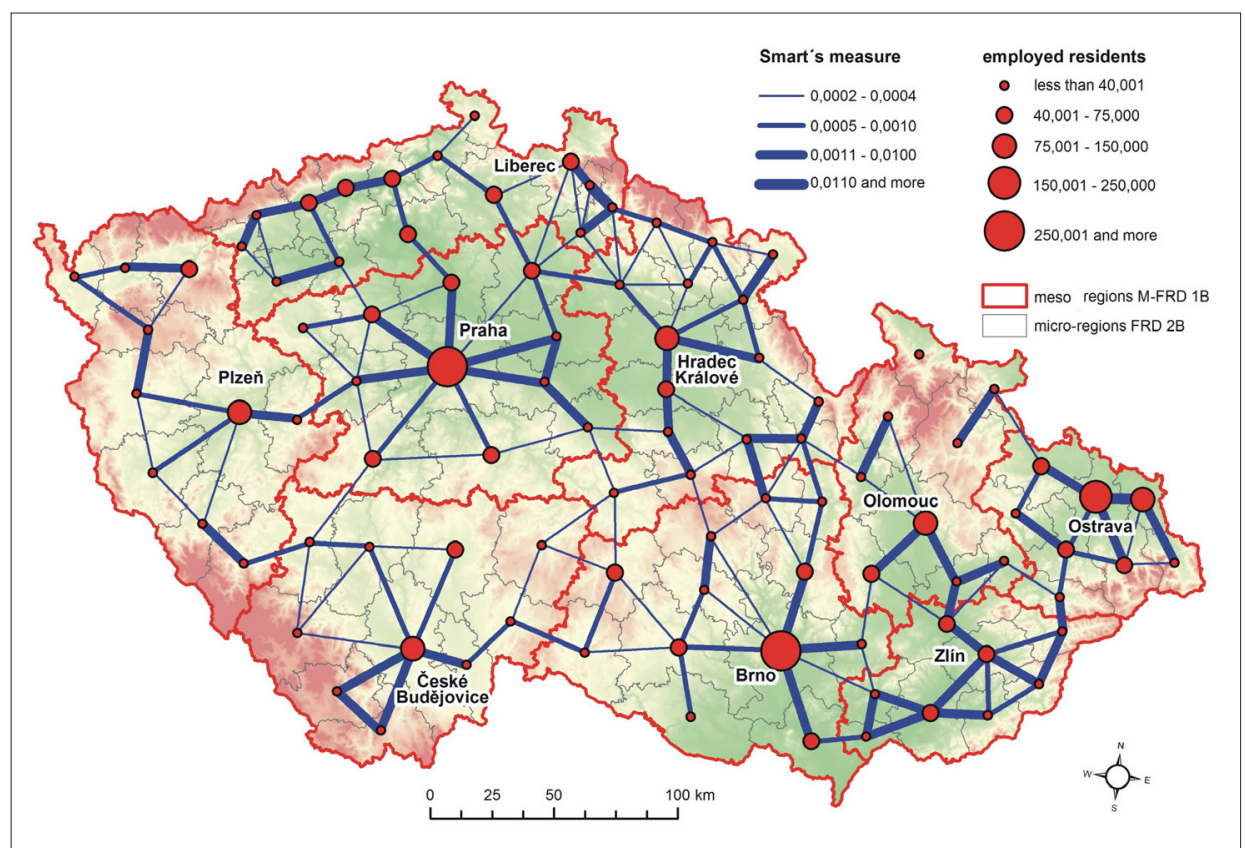

Fig. 2: Regional system M-FRD 1B. Sources: authors' elaboration, Klapka et al. (2014)

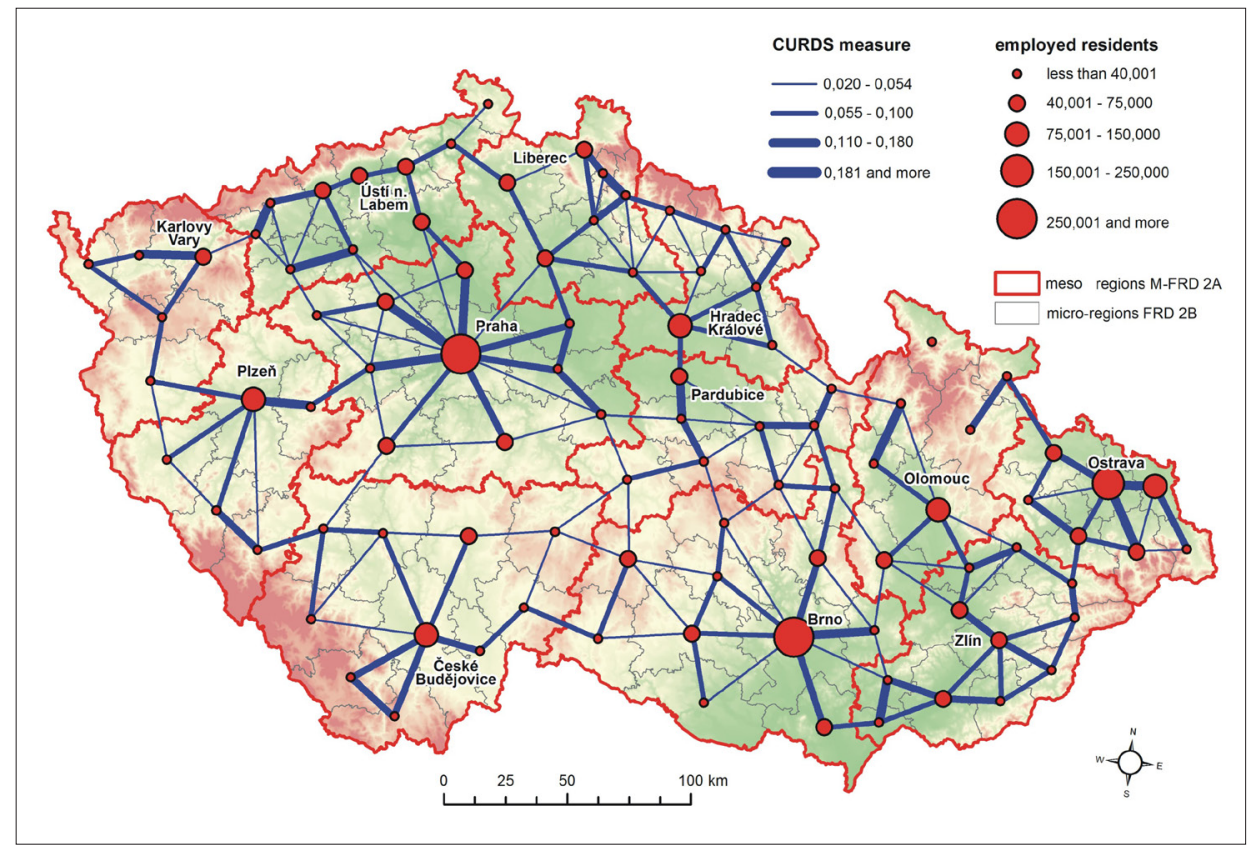

Fig. 3: Regional system M-FRD 2A. Sources: authors' elaboration, Klapka et al. (2014)

because the CURDS measure has been used for adjustments to the input interaction matrix. The variant M-FRD 2A consists of twelve meso regions, which is also the highest number of meso regions reached by the approaches used in this paper. The highest self-containment (0.982) is again in the region of northern Moravia and Silesia (Ostrava). The lowest self-containment is recorded in eastern Bohemia with two meso regions (Hradec Králové: 0.939, Pardubice: 0.926), which have significant mutual crossborder interactions due to the spatial proximity of their largest centres.

The variant M-FRD $2 \mathrm{~B}$ has amalgamated some meso regions from the variant M-FRD 2A; according to the rank of amalgamation of regions in the resulting dendrogram, the Zlin and Olomouc regions were amalgamated in Moravia, the Hradec Králové and Pardubice regions in the east of Bohemia, the Plzen and Karlovy Vary regions in the west of Bohemia, and Liberec and Ústí nad Labem regions in the north of Bohemia. This variant consists of eight meso regions, similar to the variant M-FRD 1A, both being very much alike in their spatial patterns. The difference between them lies in the meso regional affinity of some oscillating micro regions, such as Mladá Boleslav, which was removed from central Bohemia (Prague) and assigned to northern Bohemia (Liberec).

The last variant (M-FRD 3, see Fig. 5) has been produced using the Intramax approach. This meso regional system significantly differs from the preceding two pairs of systems. It consists of nine meso regions and arguably the most visible and unusual feature of this system is the spatial extent of the Brno region, which has spread along the historical border between Bohemia and Moravia, including the historically Bohemian micro-regions of Jindřichův Hradec, 


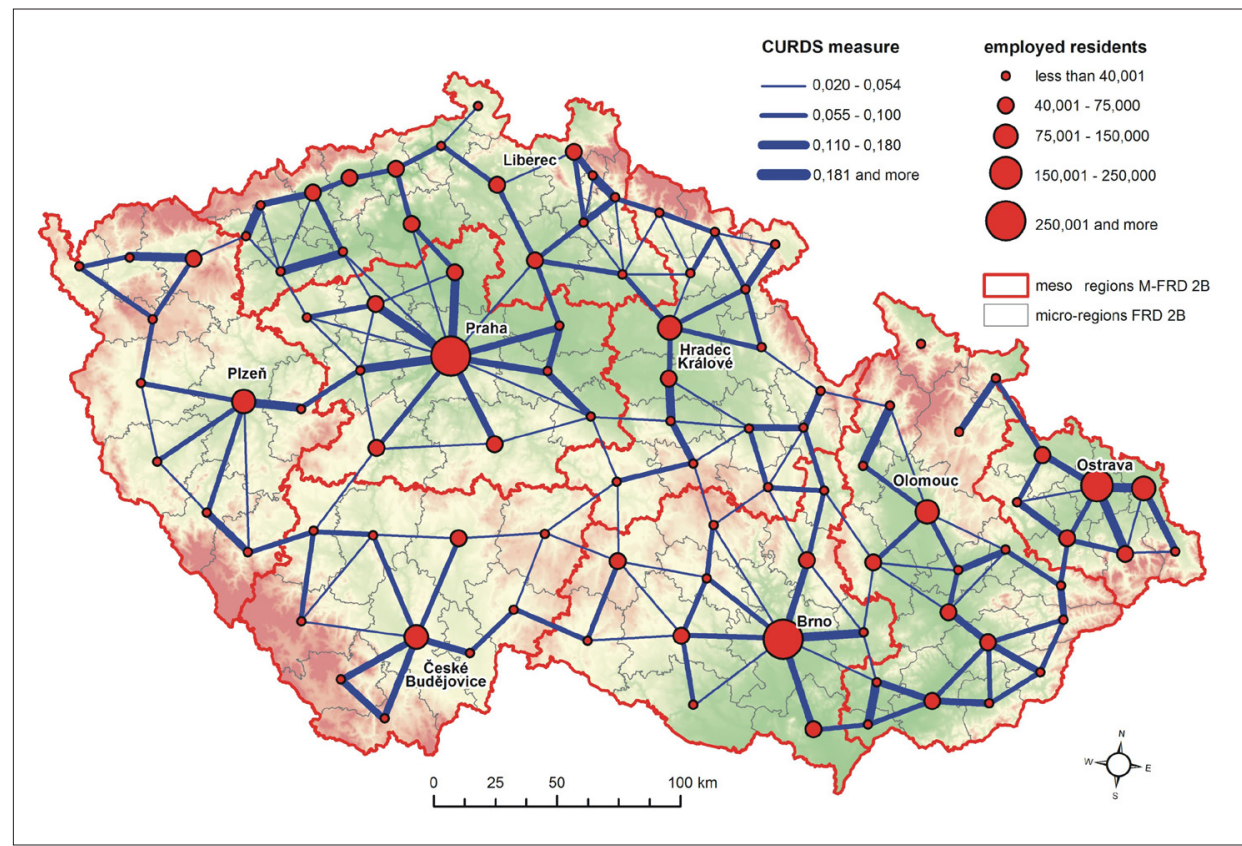

Fig. 4: Regional system M-FRD 2B. Sources: authors' elaboration, Klapka et al. (2014)

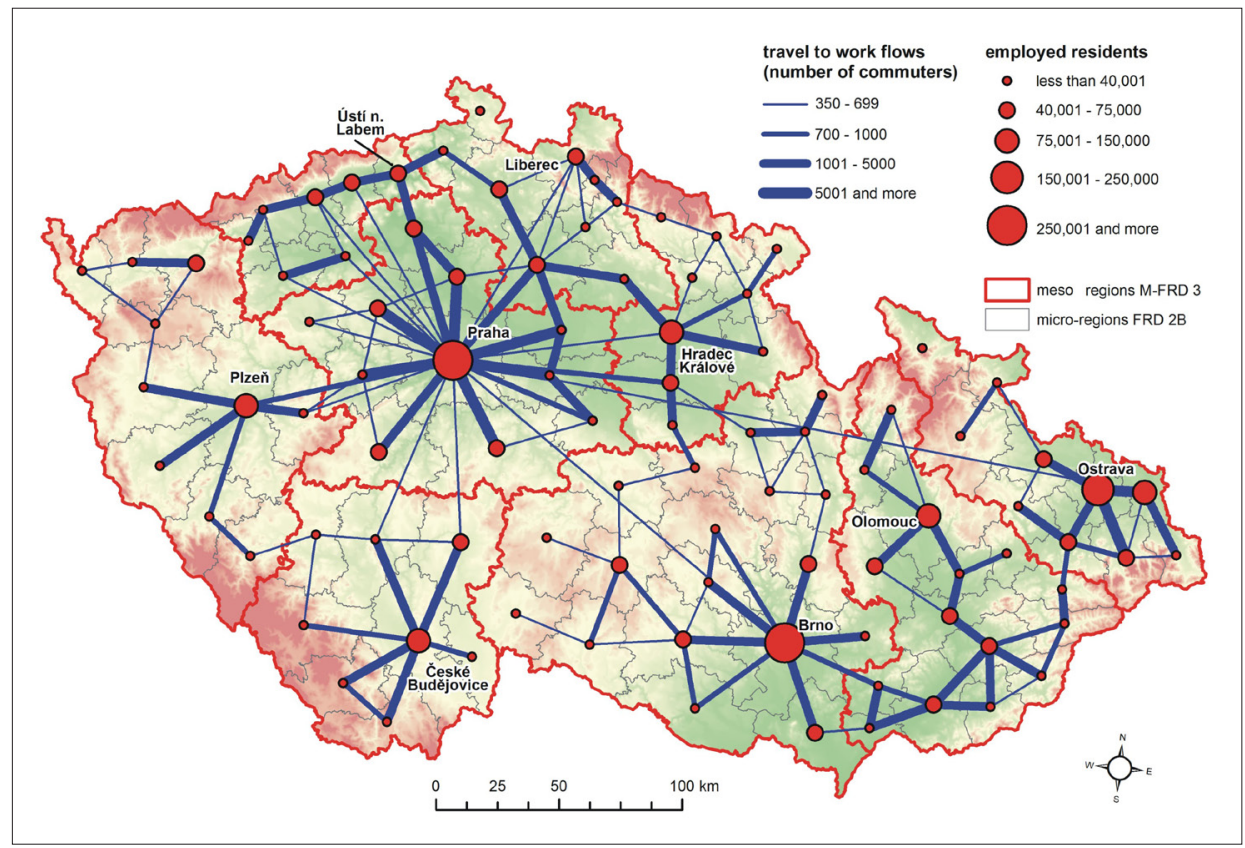

Fig. 5: Regional system M-FRD 3. Sources: authors' elaboration, Klapka et al. (2014)

Pelhřimov, Havlíčkův Brod, Hlinsko, Vysoké Mýto, Česká Třebova, Letohrad, and part of the Bohemian micro region of Svitavy. The spatial extent of northern Bohemia (Liberec) is similarly arguable. This meso region gained the micro regions of Jičín (typically assigned to eastern Bohemia) and Děčn (typically assigned to north-western Bohemia). Unlike the variant M-FRD 2B, central Bohemia (Prague) took over the micro region of Litoměrice from north-western Bohemia (Ústí nad Labem). This shift is responsible for the very low self-containment (0.945) of north-western Bohemia (Ústí nad Labem), however, which is caused by the strong crossborder interactions between the pair of micro regions Ústí nad Labem and Litoměřice.

Figure 6 presents all the functional micro regions that can be understood as oscillating. This means that during the analyses presented in this paper, they belonged to a different meso region in at least one case, when comparing all five functional meso regional systems. Naturally, the cases caused by the basic amalgamation of two meso regions which reflect different totals of meso regions in each system, are excluded from the results presented in Figure 6. It has to be admitted that a crucial role has been played by the variant M-FRD 3 in this respect, and it represents the largest spatial difference in the definitions of meso regions.

The identification of oscillating basic spatial units can be useful in processes which optimise the boundaries of regions and which are based on fuzzy set theory. The fuzziness of TTWA is examined and analysed for instance by Feng (2009), who proposed the optimisation of regional systems through the analysis and identification of the maximum values of the membership function for oscillating 


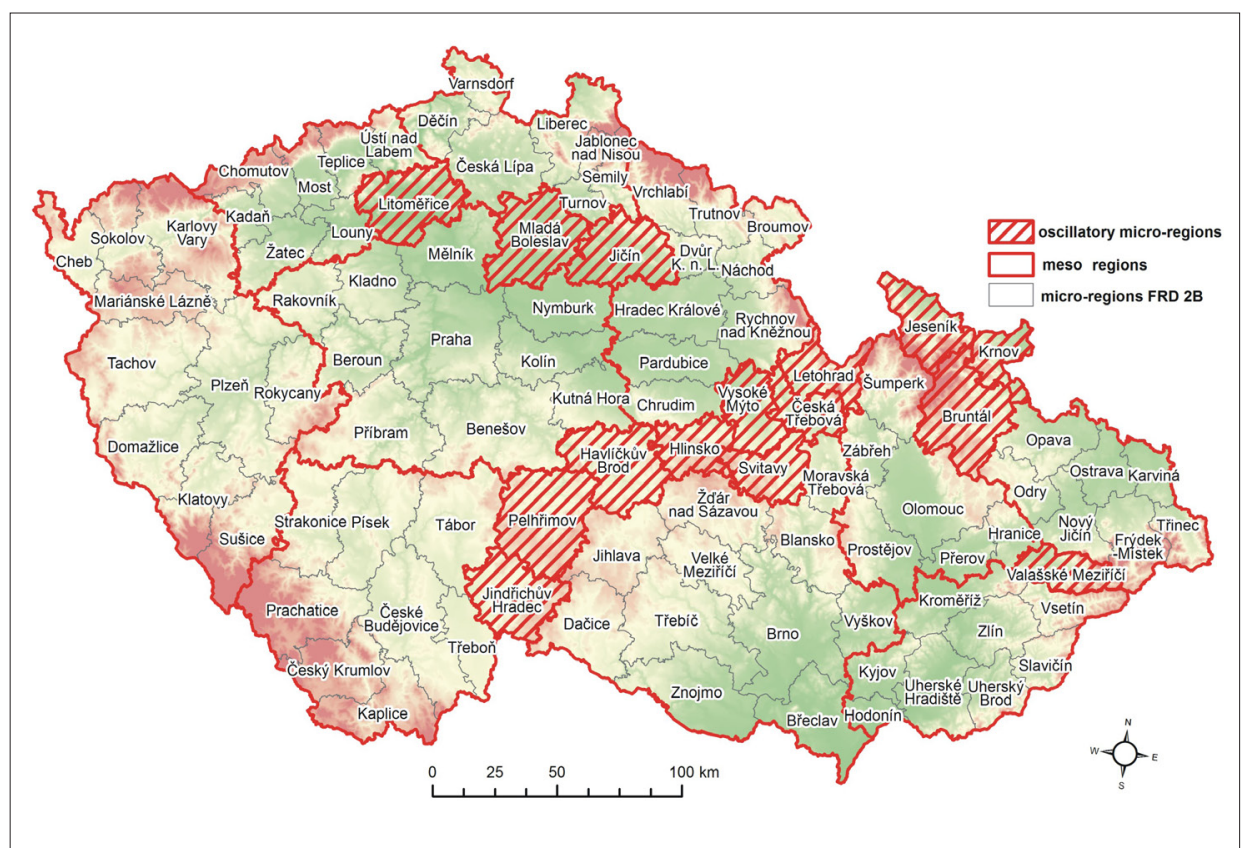

Fig. 6: Oscillating functional micro regions. Sources: authors' elaboration, Klapka et al. (2014)

basic spatial units. A similar principle was used by Kropp and Schwengler (2014) for the optimisation of LLMA.

Four spatial clusters of oscillating micro regions can be identified. The first can be found along the historical Bohemian-Moravian border (see above). The ambiguity in the affinity of these regions is conditioned by frequent and significant historical changes in the administrative division of the Czech Lands, which affected the area along the historical border between Bohemia and Moravia. The change of importance of regional centres is related to the change in commuting patterns. Until the mid of $20^{\text {th }}$ century administrative divisions had respected the historical border. This was violated by the formation of the region around Jihlava. Other regions of this type (Letohrad, Česká Třebová, Svitavy) also changed their regional affinity between the regional centres of eastern Bohemia and Moravia. A certain degree of ambiguity has been preserved until present. The second cluster is formed along the north and north-east border of central Bohemia, where the influence of the capital city Prague and the regional centres of Hradec Králové and Liberec oscillates (the micro regions of Litoměřice, Mladá Boleslav and Jičín). The third spatial cluster can be found along the western part of the border between the historical regions of Moravia and Silesia (micro regions of Jeseník, Krnov and Bruntál), whose meso regional affinity is not quite clear. The last spatial "cluster" is formed only by a single micro region (Valašské Meziříčí), which oscillates between the spheres of influence of the meso regional centres of Ostrava, Zlín or Olomouc, depending on the number of meso regions.

\section{Conclusions}

Extensive analyses of inter-micro-regional daily travel-towork flows in the Czech Republic have provided a number of meso regional patterns, out of which five have been selected for the purposes of this paper, on the basis of the total self-containment of a particular meso regional system. Three methods for the definition of meso regions have been applied, based on the labour market area approach, the
Intramax approach, and the cluster analysis approach, and previously none of these methods have been used for the Czech Republic. In order to provide sufficient insight into intra-meso regional and inter-meso regional interactions, the flows between constituent micro regions have also been analysed, using three different expressions of these flows.

The LLMA approach used an adjusted third variant of the CURDS regionalisation algorithm (multistage agglomerative procedure), which has produced two variants of the Czech meso regional system (M-FRD $1 \mathrm{~A}$ and M-FRD 1B). These two variants are based on different parameters regarding the levels of size and self-containment for the resulting functional meso regions. Both variants generally manifest a high degree of similarity; however, the application of multistage methods and the adjustments of their parameters do not produce nested regional systems.

The Intramax approach uses a hierarchical clustering procedure, which gives a single variant of the Czech meso regional system (M-FRD 3). The cluster analysis approach has provided two variants of the Czech meso regional systems (M-FRD 2A and M-FRD 2B). Even though both methods come from the principles of cluster analysis, they differ in linkage measures and in the adjustment of the input interaction (data matrix), and their results are considerably different. Unlike the multistage methods, they are able to provide nested variants for regional systems of different and similar hierarchical levels (see the variants M-FRD 2A and M-FRD 2B). This is secured by the analysis of outputs in the form of a dendrogram.

All five variants for functional meso regional systems of the Czech Republic conform to the normalised categories of either NUTS 2 regions or NUTS 3 regions (the case of variant M-FRD 2A). Generally, it can be concluded that all three methods are suitable for a definition of functional meso regions, even though there are some differences in respective meso regional patterns. In this respect, four spatial clusters of so-called oscillating functional micro regions have been identified. Finally, the functional micro regions have shown that they can act as suitable building blocks for their amalgamation into higher-level hierarchical regions. 


\section{Acknowledgement}

The paper has been supported by the project of the Czech Science Foundation: "Spatial uncertainty and fuzzy regional systems: identification, analysis and implications of pulsating functional regions" (16-13502S). The authors are grateful for this support.

\section{References:}

BALL, R. M. (1980): The use and definition of travel-to-work areas in Great Britain: some problems. Regional Studies, 14(2): 125-139.

BERRY, B. J. L. (1973): Growth centers in the American urban system: Community development and regional growth in the sixties and seventies. Cambridge: Ballinger Pub. Co.

BEZÁK, A. (2000): Funkčné mestské regióny na Slovensku. Geographia Slovaca, 15, Bratislava: Geografický ústav SAV.

BROWN, L. A., HOLMES, J. (1971): The delimitation of functional regions, nodal regions, and hierarchies by functional distance approaches. Journal of Regional Science, 11(1): 57-72.

CASADO-DÍAZ, J. M. (2000): Local labour market areas in Spain: a case study. Regional Studies, 34(9): 843-856.

CASADO-DÍAZ, J. M. (2003): The use of commuting data to define local labour market areas and urban areas in Spain. Paper presented at $7^{\text {th }}$ NECTAR Conference, Umeĺ University, Sweden.

CHRISTALLER, W. (1933): Die zentralen Orte in Süddeutschland. Jena: Fischer.

COOMBES, M. G. (2010): Defining labour market areas by analysing commuting data: innovative methods in the 2007 review of Travel-to-Work Areas. In: Stillwell, J., Duke-Williams, O., Dennett, A. [eds.]: Technologies for migration and commuting analysis: spatial interaction data applications (pp. 227-241). Hershey: IGI Global.

COOMBES, M. G., BOND, S. (2008): Travel-to-Work Areas: the 2007 review. Office for National Statistics, London.

COOMBES, M. G., DIXON, J. S., GODDARD, J. B., OPENSHAW, S., TAYLOR, P. J. (1982): Functional regions for the population census of Great Britain. In: Herbert, D. T., Johnston, R. J. [eds.]: Geography and the Urban Environment. Progress in Research and Applications 5, Chichester: John Wiley, p. 63-112.

COOMBES, M. G., GREEN, A. E., OPENSHAW, S. (1986): An Efficient Algorithm to Generate Official Statistical Reporting Areas: The Case of the 1984 Travel-to-Work Areas Revision in Britain. The Journal of the Operational Research Society, 37(10): 943-953.

De JONG, T., Van der VAART, N. (2010): Manual Flowmap, Faculty of Geographical Sciences, Utrecht University, Utrecht [online]. [cit. 13.10.2015], Available at: http:// flowmap.geo.uu.nl/downloads/FM740_Manual.pdf

DROBNE, S., BOGATAJ, M. (2012): Evaluating Functional Regions. Croatian Operational Research Review, 3: 14-26.

DROBNE, S., KONJAR, M., LISEC, A. (2009): Delimitation of Functional Regions Using Labour Market Approach. In: Zadnik Stirn, L., Žerovnik, J., Drobne, S., Lisec, A. (ed.): Proceedings of SOR'09, $10^{\text {th }}$ International
Symposium on Operational Research in Slovenia, Slovenian Society Informatika, Section for Operational Research (pp.417-425). Ljubljana, Slovenia.

ERLEBACH, M., KLAPKA, P., HALÁS, M., TONEV, P. (2014): Inner structure of functional region: theoretical aspects. In: $17^{\text {th }}$ International Colloquim on Regional Science. Conference Proceedings. (Hustopeče 18.-20.6. 2014) (pp. 722-727). Masarykova univerzita, Brno.

FARMER, C. J. Q., FOTHERINGHAM， A. S. (2011): Network-based functional regions. Environment and Planning A, 43(11): 2723-2741.

FENG, Z. (2009): Fuzziness of Travel-to-Work Areas. Regional Studies, 43(5): 707-720.

GUSTAFSON, G. C. (1973): Numerical Classification Procedures. LARS Symposia. Paper 16.

HAGGETT, P. (1965): Locational Analysis in Human Geography. London: Arnold.

HALÁS, M., KLAPKA, P. (2010): Regional division of Czechia on the basis of spatial interaction modelling. Geografie, 115(2): 144-160.

HALÁS, M., ZUSKÁČOVÁ, V. (2013). Travelling to services in the daily urban system of Olomouc. Bulletin of Geography, Socio-economic Series, 20: 23-41.

HALÁS, M., KLAPKA, P., TONEV, P. (2014a): A contribution to human geographical regionalisation of the Czech Republic at the mezzo level. In: $17^{\text {th }}$ International Colloquim on Regional Science. Conference Proceedings. (Hustopeče 18.-20.6. 2014) (pp. 715-721). Masarykova univerzita, Brno.

HALÁS, M., KLAPKA, P., BLEHA, B., BEDNÁŘ, M. (2014b): Funkčné regióny na Slovensku podl'a denných tokov do zamestnania. Geografický časopis, 66(2): 89-114.

HALÁS, M., KLAPKA, P., BEDNÁŘ, M., TONEV, P. (2015): An alternative definition and use for the constraint function for rule-based methods of functional regionalisation. Environment and Planning A, 47(5): 1175-1191.

HALL, P. G., HAY, D. (1980): Growth centres in the European urban system. London: Heinemann.

HOLMES, J. H., HAGGETT, P. (1977): Graph theory interpretation of flow matrices: a note on maximization procedures for identifying significant links. Geographical Analysis, 9(4): 388-399.

ISARD, W. (1956): Location and space economy: A general theory relating industrial location, market areas, land use, trade and urban structure. New York: John Wiley.

KARLSSON, C., OLSSON, M. (2006): The identification of functional regions: theory, methods, and applications. The Annals of Regional Science, 40(1): 1-18.

KLAPKA, P., HALÁS, M., TONEV, P. (2013a): Functional regions: concept and types. In: $16^{\text {th }}$ International Colloquium on Regional Sciences, Conference Proceedings (pp. 94-101). Brno: Masaryk University.

KLAPKA, P., HALÁS, M., TONEV, P., BEDNÁŘ, M. (2013b): Functional regions of the Czech Republic: comparison of simple and advanced methods of regional taxonomy. Acta Universitatis Palackianae Olomucensis, Facultas Rerum Naturalium, Geographica, 44(1): 45-57.

KLAPKA, P., HALÁS, M., ERLEBACH, M., TONEV, P., BEDNÁŘ, M. (2014): A multistage agglomerative 
approach for defining functional regions of the Czech Republic: The use of 2001 commuting data. Moravian Geographical Reports, 22(4): 2-13.

KONJAR, M., BOYANDIN, I., LALANNE, D., LISEC, A., DROBNE, S. (2010): Using flow maps to explore functional regions in Slovenia. The Proceedings of the 2nd International Conference on Information Society and Information Technologies. Dolenjske Teplice.

KROPP, P., SCHWENGLER, B. (2014): Three-Step Method for Delineating Functional Labour Market Regions. Regional Studies, 50(3): 429-445.

LANDRÉ, M. (2012): Geoprocessing Journey-to-Work Data: Delineating Commuting Regions in Dalarna, Sweden. ISPRS Int. J. Geo-Inf, 1: 294-314.

LANDRÉ, M., HÅKANSSON, J. (2013): Rule versus interaction function: evaluating regional aggregations of commuting flows in Sweden. European Journal of Transport and Infrastructure Research, 13(1): 1-19.

LÖSCH, A. (1940): The Economics of Localization. Jena, Fischer.

MASSER, I., BROWN, P. J. B. (1975): Hierarchical aggregation procedures for interaction data. Environment and Planning A, 7(5): 509-523.

MASSER, I., SCHEURWATER J. (1980): Functional regionalisation of spatial interaction data: an evaluation of some suggested strategies. Environment and Planning A, 12(12): 1357-1382.

MITCHELL, W. F., WATTS, M. J. (2010). Identifying functional regions in Australia using hierarchical aggregate techniques. Geographical Research, 48(1): 24-41.

NYSTUEN, J. D., DACEY, M. F. (1961): A graph theory interpretation of nodal regions. Regional Science Association, Papers and Proceedings, 7(1): 29-42.

OECD (2002): Redefining Territories: The Functional Regions. Paris: OECD.
PAPPS, K. L., NEWELL, J. O. (2002): Identifying functional labour market areas in New Zealand: a reconnaissance study using travel-to-work data. Discussion Paper 443. Bonn: Institute for the Study of Labor.

PHILBRICK, A. K. (1957): Principles of areal functional organization in regional human geography. Economic Geography, 33(4): 299-336.

ROUSSEEUW, P. J. (1987): Silhouettes: A graphical aid to the interpretation and validation of cluster analysis. Journal of Computational and Applied Mathematics, 20: 53-65.

SMART, M. W. (1974): Labour market areas: uses and definition. Progress in Planning, 2(4): 239-353.

SÝKORA, L., MULÍČEK, O. (2009): The micro-regional nature of functional urban areas (FUAs): lessons from the analysis of Czech urban and regional system. Urban Research and Practice, 2(3): 287-307.

THÜNEN, von J. H. (1826), Der Isolierte Staat in Beziehung auf Landschaft und Nationalökonomie. Trans. By C. M. Wartenberg (1966): Von Thünen's Isolated State. Oxford: Pergamon Press.

TONEV, P. (2013): Změny v dojížd'ce za prací v období transformace: komparace lokálních trhů práce. Diploma thesis. Brno: Masaryk University.

WARD, J. H. (1963): Hierarchical grouping to optimize an objective function. Journal of the American Statistical Association, 58: 236-244.

WATTS, M. (2009): Rules versus hierarchy: an application of fuzzy set theory to the assessment of spatial grouping techniques. In: Kolehmainen, M., Toivanen, P. J., Beliczynski, B. [eds.]: ICANNGA 2009, LNCS, 5495: 517-526.

WONG, D. (2009): The modifiable areal unit problem (MAUP). In: Fotheringham, A., Rogerson, P. [eds.]: The SAGE handbook of spatial analysis (pp. 105-125). London: SAGE Publications Ltd.

\section{Please cite this article as:}

ERLEBACH, M., TOMÁŠ, M., TONEV, P. (2016): A functional interaction approach to the definition of meso regions: The case of the Czech Republic. Moravian Geographical Reports, 24(2): 37-46. Doi: 10.1515/mgr-2016-0009. 